\title{
Research on the Construction of Practical Teaching Model of Radio and Television Directing Specialty in Local Universities
}

\author{
Jiang Chunxu ${ }^{\mathrm{a}}$, Qu Qinghong ${ }^{\mathrm{b}}$ \\ ${ }^{1}$ Baicheng Normal University, Baicheng 137000, China \\ aemail: 115721119@qq.com, bemail: quqinghong@163.com
}

Keywords: Radio and Television Professional; Practice; Teaching Mode; Research

\begin{abstract}
With the continuous development of film and television industry, the social demand for talent is increasing. The media for media personnel training in colleges and universities is an important content. The director of professional radio and television should strengthen practice teaching, broaden the practice teaching space, improve the cultivation platform. This paper will analyze the practice teaching mode of local radio and television university the director of professional, put forward the corresponding improvement measures.
\end{abstract}

\section{Introduction}

In recent years, with the continuous development of media industry, the director of professional radio and television have great reform. Local colleges have offered many radio and television professionals. But vigorously expand enrollment enrollment also exposed some problems, such as the school of shortage of teachers, teaching resources and equipment related to radio and television is a lack. A collection of creative, editing, planning and other professional disciplines, for students' practice ability is relatively high[1]. The current society on radio and television professional talents is relatively weak, based on the student's mastery of the strong, in the actual operation is emerging. For the radio and television professional in terms of the need to continue to reform, strengthen the emerging professional capital investment, strengthen the construction of teacher education resources. For these measures to vigorously develop Social development of talents, training a number of application-oriented social talents to provide protection.

\section{The Necessity of the Reform of Radio and Television Directing Major in Local Universities}

With the rapid development of China's economy, people's living standard rising, people in the pursuit of material enjoyment at the same time, is also in constant pursuit of spiritual satisfaction. At the same time, the rapid development of information technology, the Internet has been widely used in people's lives, but also brought great convenience to people's lives in this. Under the social background, the media industry has been the rapid development of the media industry talent demand is increasing. The development of colleges and universities is to cultivate the professional talents, it is also an important base of Culture Radio and television talent. However, the traditional teaching in Colleges and universities, more traditional teaching ideas and teaching methods can not adapt to the current needs of society talents, the traditional teaching mode pays too much attention to the students' theoretical knowledge learning, limits the students hands-on practice ability, talent cultivation and social development Trends are disjointed and the media industry is constantly changing, leading to school education that can't keep pace with it[2].

\section{Problems Existing in the Teaching Mode of Traditional Radio and Television Director}

Director of professional radio and television is an applied and practical professional. Director of professional radio and television has been an important direction in the teaching practice of personnel training in Colleges and universities, with most of the professional practice teaching related. Radio and television professional practice includes practice teaching and extracurricular practice in two parts. In the course of practice is the main course of TV interview, but some news 
writing and editing arrangement, the related teaching contents need to be completed under the guidance of teachers. The school should carry on knowledge with hands-on practice related to classroom learning, students need to enter the media industry practice, practice in the relevant the media staff under the guidance of the media industry to actual contact work. In the process of practice, theory of knowledge can be learned in class To make full use of the practice, a solid foundation of knowledge and learning, and consolidate the supplement to the extracurricular practice, only the organic combination of them, in order to better do a good job in the media, the media to understand the work processes and content. However, in the training of the actual teaching, the combination of learning and practice not many in class [3]. This is mainly reflected in: the university funds many relatively scarce and relatively backward in teaching facilities, a lot of media technology can not be compared with some technical equipment. The students in the process of practice in learning, not learning some of the advanced equipment, after entering the internship, for the operation process not some new media devices to adapt quickly. At the same time, the number of equipment can not meet the needs of the students, but also can not reach a certain teaching effect; the second is many In the radio and television professional teachers is not enough. Some teachers are lack of practical ability, have rich practical experience. So in the actual teaching process, can not be a good guide for students, teaching pertinence is not strong. In such a situation, the students to master the practical skills of comparison slow; the third is the rapid development of information technology, the application of information technology in the media industry more and more widely, the media industry business development in the ongoing reform, the relevant aspects of the mode of radio and television has been updated, and the application of the school's teaching practice is not a formal approach to information technology in the professional; the fourth is the media most of the work intensity is relatively large, running faster, after most of the interns to enter the media industry the opportunity to participate in the practical work, to see the traditional teaching model for college students is relatively large, not timely reform is difficult to adapt to the current needs of the development of the society.

\section{The Necessity of Practical Teaching and Training Model for Radio and Television Directing Specialty}

Meet the Needs of the Current Social Application-Oriented Talents Training. The rapid development of social economy and information technology, put forward higher requirements for the relevant personnel of radio and TV director. Students should not only have a solid theoretical foundation of knowledge and art appreciation, but also have the practical ability. This teaching on the request. In the process of personnel training in Colleges and universities. We should pay attention to the cultivation of students' comprehensive practical ability. The school training program in the formulation of relevant personnel, need to do a detailed demonstration and research work, but also learn from the successful experience of some elite schools. According to the talents training mode reform, the reform should combine the actual situation of the students of related patterns.

Demand for Related Jobs in the Media Industry. After entering the society the radio and television professional students can choose the practice unit of television, film and television companies, advertising companies or Internet media company, in the unit needs to assume the reporter, director, some post production. But for these enterprises, the general acceptance of the intern is limited. So in the process of the school teaching, to provide students with more opportunities to practice and internship, students can quickly adapt to the society. Post school in the teaching process, according to the students' interests and development of the media industry trend, arrange for students to select the appropriate job training for students after entering the post lay a good foundation.

The Need to Improve Students' Practical Skills. Radio and television professional practice is very strong. The school should adopt the certain teaching mode of assessment of students in the teaching process. Teachers can cooperate with relevant internship units, to establish a practical evaluation system. For example, can arrange a studio, small groups of students to choose their own form of group the subject. So that the students in the process of cooperation, can communicate with 
each other, can also evaluate the scoring, with a faster progress of students.

To Achieve the Maximum Utilization of Resources. The practice of television directing specialty is very strong, and its theoretical knowledge is also applied in practice. In the teaching process, to cultivate applied talents, need to have strong facilities as a support, but also need to have a strong faculty, according to the current development situation of the media industry to reform. The current social media industry for the needs of students and television professional, some schools in enrollment the scale is also expanding, school related facilities and equipment can not meet the needs of the students. The school should be based on making full use of resources, continue to add new facilities and equipment to carry out various forms of practice, fully enhance students' practical ability.

\section{Analysis of Practical Teaching Measures for Radio and Television Directing Majors in Universities}

In the training process, colleges and universities according to the current development situation of the media industry to develop relevant personnel training programs[4]. The media industry in the process of rapid development, need a large number of professional talents. Colleges and universities in the talent training goal, to keep up with the trend of the times, to make objective analysis according to the school's running at present conditions of personnel training in Colleges and universities to strengthen students' practice of editing, between the camera and so on, to cultivate students' practical ability, let the students after entering the community, can adapt to related work.

Making Personnel Training Programs. In the radio and TV directing students' talents training target, the first to develop is training plan. The plan of personnel training in Colleges and universities is an important guarantee for the establishment of personnel training, personnel training strategy, strengthen students' practical curriculum, strengthening the practice skills of students, let the students in learning theory knowledge and to apply theory to practice. Learn to break a traditional teaching mode, to enhance students' interest in learning, cultivate students' team cooperation ability. For example, the high school graduation design is an important part of talent training in radio and television professional, teachers should arrange the graduation design as an important project to improve the practice ability of the students. Students can own content can be prepared in advance, making small video, video clips, and combine their own work related The content of the paper, but also the theory of knowledge to students. Students can do a test through the form of cooperation, cooperation between team members, for each part of the work need to arrange corresponding personnel, but also on the practical ability of students study, improve students' cooperation. At the same time can also hold some lectures, increase among students the exchange of learning, celebrities can invite the media industry of topics to explain, understand the dynamic of the media industry, let the students have access to some of the new content in the society in advance, broaden their horizons, let the students understand the new media thought.

Increasing the Construction of School Teachers. School excellent teachers can improve the teaching quality of professional[5]. For television professional students, teachers need to have rich theoretical knowledge and practical experience. First, teachers should be able to grasp the dynamics of the news media industry, in order to better teach students some content. For example, school teachers can related to radio and television Choose to go to college some investigation and research, or to some of the media industry to conduct training, learn some experience in practice, enhance the ability of practice. At the same time can employ some of the media industry or the teacher of the school of practical experience for students to teach, students can learn the most advanced knowledge, enhance students' knowledge, can invite some program director or journalist is teaching some professional practices.

Adopting "School Enterprise Cooperation" Teaching Method. Radio and television is a professional and practical professional[6]. A large number of students only through practice, to improve their practical ability. For colleges and universities often lack the most advanced facilities and equipment, and the media industry with advanced facilities and equipment. In cooperation with the relevant enterprises, let the students you can enter the actual work in practice, students can learn 
the most advanced ideas in the enterprise, from the simulation project in school into the real project, students can realize the standards and society. For example, after entering the practice base, the establishment of a "practice teaching system, aiming at the studio" the student's strengths and interests, arrange suitable jobs, let the students into the real media industry practice, can arouse the students' interest in learning, let students to After entering the society prepared. This practice teaching mode, a teaching system is popular, in the classroom theoretical knowledge and practical operation is fully integrated, breaking the traditional boring teaching mode. In the studio tasks, students can according to the specific circumstances, the free component group work in video production, students can be responsible for different tasks, for these different studios, although the independent existence, but they are interrelated, students must complete the task within the prescribed period of time.

\section{Conclusion}

To sum up, with the continuous development of the media industry, for radio and television professional talent demand is gradually increasing, radio and television is a practical professional and practical ability for the students is relatively high. For some colleges and universities should reform the teaching mode, strengthen the construction of teachers, optimizing the course the content set, increase the relevant facilities and equipment investment, the establishment of school enterprise cooperation. We should vigorously cultivate students' practical ability, according to the trend of the school and the development of the media industry development status of the reform.

\section{Acknowledgement}

In this paper, the research was sponsored by the Educational Science Project of Jilin province during “13th Five-Year Plan” in 2017 (No. GH170595).

\section{References}

[1] Wang Wei. An analysis of the practice teaching mode of broadcast television-take the example of professional training [J]. Journal of News Research, 2016,70

[2] Chen Jun. To explore the teaching mode of comprehensive broadcast television based on "three-room integration"[J].West China Broadcasting TV, 2016,11

[3] Li Geng. Research on the professional practice teaching mode of broadcast television [J]. Heilongjiang Education(Higher Education Research \& Appraisal), 2014,06

[4] Qiu Yue. A study on the reform and innovation of the professional practice teaching of radio and television in private universities [J]. Journal of Inner Mongolia Normal University(Philosophy and Social Sciences Edition), 2016,45

[5] Zhu Mengyu. Study on the teaching mode of radio and television choreographing professional practice - assessment of radio and TV guide course[J].Journalism Lover, 2017,08

[6] Zhao Qianqian. Research on the practice teaching mode of broadcast television [J]. Literature Education, 2015,09 